\title{
Circulating miRNAs in HER2-Positive and Triple Negative Breast Cancers: Potential Biomarkers and Therapeutic Targets
}

\author{
Ishita Gupta ${ }^{1,2}\left(\right.$, Balsam Rizeq ${ }^{1,2}\left(\mathbb{D}\right.$, Semir Vranic ${ }^{1} \oplus$, Ala-Eddin Al Moustafa ${ }^{1,2, *(\mathbb{D}}$ and \\ Halema Al Farsi 1,* \\ 1 College of Medicine, QU Health, Qatar University, Doha P.O. Box 2713, Qatar; \\ ishugupta28@gmail.com (I.G.); balsamr@gmail.com (B.R.); svranic@qu.edu.qa (S.V.) \\ 2 Biomedical Research Centre, Qatar University, Doha P.O. Box 2713, Qatar \\ * Correspondence: aalmoustafa@qu.edu.qa (A.-E.A.M.); halfarsi@qu.edu.qa (H.A.F.); \\ Tel.: +974-4403-7817 (A.-E.A.M.); +974-4403-7840 (H.A.F.)
}

Received: 27 July 2020; Accepted: 6 September 2020; Published: 15 September 2020

\begin{abstract}
Breast cancer is one of the most prevalent diseases among women worldwide and is highly associated with cancer-related mortality. Of the four major molecular subtypes, HER2-positive and triple-negative breast cancer (TNBC) comprise more than $30 \%$ of all breast cancers. While the HER2-positive subtype lacks estrogen and progesterone receptors and overexpresses HER2, the TNBC subtype lacks estrogen, progesterone and HER2 receptors. Although advances in molecular biology and genetics have substantially ameliorated breast cancer disease management, targeted therapies for the treatment of estrogen-receptor negative breast cancer patients are still restricted, particularly for TNBC. On the other hand, it has been demonstrated that microRNAs, miRNAs or small non-coding RNAs that regulate gene expression are involved in diverse biological processes, including carcinogenesis. Moreover, circulating miRNAs in serum/plasma are among the most promising diagnostic/therapeutic tools as they are stable and relatively easy to quantify. Various circulating miRNAs have been identified in several human cancers including specific breast cancer subtypes. This review aims to discuss the role of circulating miRNAs as potential diagnostic and prognostic biomarkers as well as therapeutic targets for estrogen-receptor negative breast cancers, HER2+ and triple negative.
\end{abstract}

Keywords: circulating miRNAs; breast cancer; HER2-positive; triple negative breast cancer; receptor negative breast cancer; biomarkers

\section{Introduction}

Breast cancer is the second most common cancer worldwide, and it affects more than two million women accounting for around half a million deaths annually [1]. Breast cancer is a heterogeneous disease with several pathological features that are associated with disease prognosis and therapeutic options [2]. Microarray profiling classifies breast cancer into four molecular subtypes (luminal (A and B), HER2-positive and triple-negative breast cancer (TNBC)) with distinct gene expression patterns and clinical outcomes [3-5]; HER2-positive and TNBC subtypes are comparatively aggressive [6,7] and lack hormone receptors and hence are known as receptor negative breast cancers [8].

In comparison to other subtypes, HER2-positive breast cancer is characterized by the amplification/overexpression of HER2 protein and accounts for $15-20 \%$ of breast cancer cases $[9,10]$. The oncogene, HER2 (ERBB2) encodes a tyrosine kinase receptor which stimulates oncogenic pathways associated with increased cellular proliferation, invasion as well as angiogenesis. HER2-positive 
subtype is prone to lymph node metastasis and correlates with poor prognosis, short survival, and high rates of recurrence $[6,10,11]$.

On the other hand, TNBC, lacks the expression of the three receptors (ER, PR and HER-2/neu); TNBC accounts for around $12-17 \%$ of all breast cancer cases [7]. Comparatively, TNBC commonly affects younger patients, and is characterized by advanced stage, higher Ki-67 proliferative index and advanced histologic grades [12-15]. In TNBCs, metastasis frequently occurs to visceral organs and bone [16-18]; in addition, cerebral metastasis is the most common [19-21].

Treatment for HER2-positive breast cancer involves targeted therapy using monoclonal antibodies, such as trastuzumab (Herceptin); which target the HER2 receptor and inhibit its associated pathways regulating proliferation, survival, migration and cell invasion [22]. Other available treatments include lapatinib [23], pertuzumab, ado-trastuzumab emtansine (T-DM1), trastuzumab deruxtecan (DS-8201), neratinib, and tucatinib [24,25].

Since TNBC cells are deficient in ER, PR and HER2 receptors, treatment options are presently limited; hence, cytotoxic chemotherapy is the standard approach for TNBCs thus far [26,27]. As such, new therapeutic options for this group of breast cancers are highly needed. In this regard, recent studies have shown great promise by targeting $P D-L 1$ receptors using immune checkpoint inhibitors. This is particularly important as PD-L1 expression is present in advanced TNBCs, thus providing the opportunity for treatment with immunomodulatory drugs or anti-PD-1/PD-L1 therapies [28-31].

Nevertheless, although estrogen-receptor negative breast cancer initially responds well to therapy, it generally becomes resistant with higher rate of recurrence compared to other subtypes of breast cancers, resulting in tumor progression and death in around $90 \%$ of patients with advanced/metastatic disease [32,33].

On the other hand, several recent studies have shown that microRNAs (miRNAs) can provide a potential diagnostic and therapeutic approach for human breast cancers including estrogen-receptor negative breast cancers [34-36]. Moreover, circulating miRNAs can be used as a non-invasive tool for early diagnosis and provide a new avenue for estrogen-receptor negative breast cancer management [37]. In this review we will summarize the recent advances made in the identification and role of estrogen-receptor negative specific circulating miRNAs.

\section{Circulating miRNAs (ci-miRNAs)}

MiRNAs belong to the class of small non-coding RNAs, measuring around 25nt in length. miRNAs have structural, regulatory as well as catalytic functions at the post-transcriptional level [38-40]. While, miRNAs can degrade or inhibit mRNA translation by targeting $3^{\prime}$ untranslated region (UTR), they are also known to target the $5^{\prime}$ UTR, gene promoters and coding sequences [41,42]. While, miRNA synthesis process is tightly controlled; dysregulation of miRNA expression alters several cellular processes including transcription, signal transduction, proliferation, growth, differentiation as well as apoptosis [43-45], thus, indicating their role in the onset and progression of cancer. In addition, miRNAs mediating metastasis have been identified and act as metastasis activators or suppressors [46,47]. These miRNAs play a vital role in metastatic cascade, including migration, invasion, adhesion, epithelial-mesenchymal transition (EMT), extracellular matrix modification and proliferation at the distant site. During carcinogenesis, miRNAs can act as both, oncomiRNAs (Figure 1) as well as tumor suppressors [48-51].

Since, miRNAs play a vital role in cancer initiation and progression, there is a wide spectrum of latent applications of miRNA measurements in oncology. Discovery of miRNAs in biofluids has paved the way for their role as biomarkers in the diagnosis of various diseases including neurodegenerative [52], cardiovascular diseases [53], diabetes [54] and cancer [55]. Moreover, in comparison to normal tissues, tumor samples from the same patient differentially express miRNAs [56,57]; unique miRNA expression patterns are present in several cancers such as prostate [58], colon [59], gastric [60], ovary [61] and breast [62]. Stability of miRNAs facilitates their detection in circulation, thus, circulating miRNAs can 
serve as potential biomarkers that can be measured repeatedly and non-invasively in several types of cancer [63].

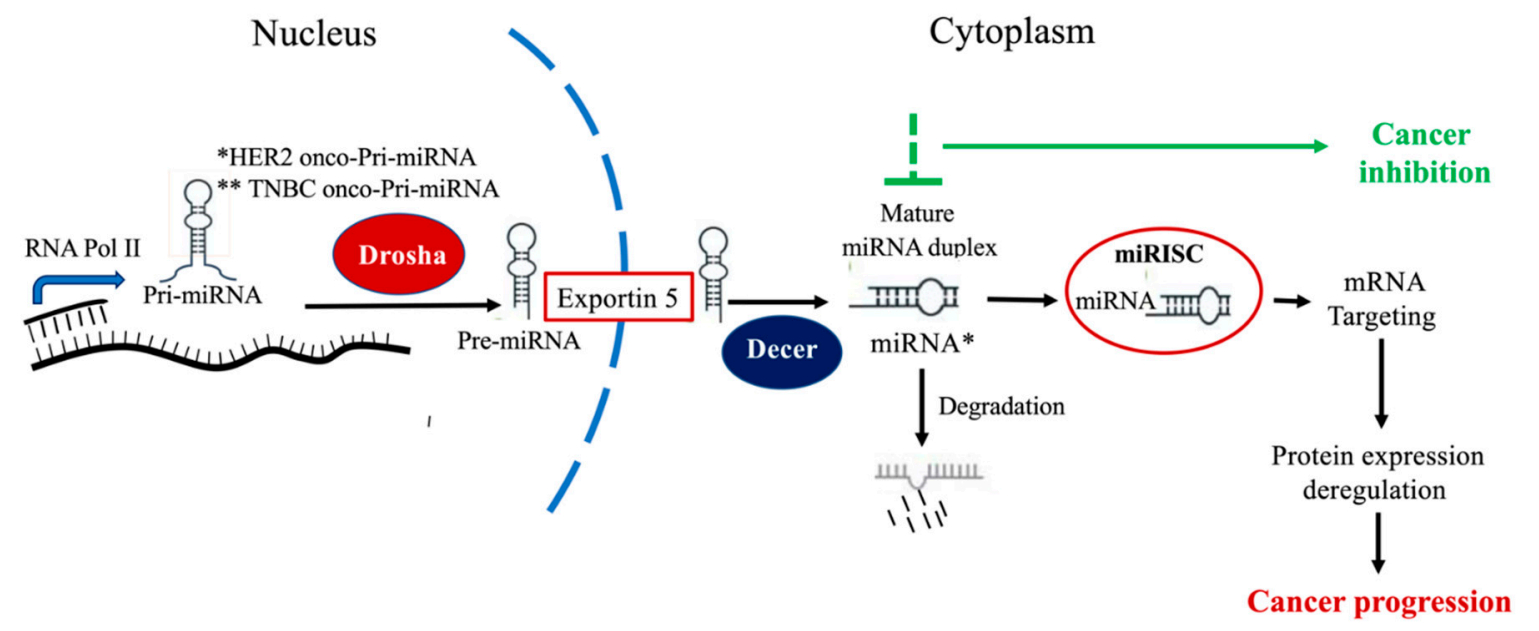

Figure 1. Schematic outline of miRNA biogenesis in "*HER2 and ${ }^{* *}$ TNBC" cells. Synthesis of primary miRNA (pri-miRNA), by RNA pol II precedes sequential nuclear processing by the microprocessor complex containing Drosha. Then, export of miRNA precursor (pre-miRNA) to the cytoplasm is carried out via Exportin 5 followed by removal of the loop region in the pre-miRNA by an endonuclease complex containing Dicer to generate a mature miRNA/miRNA* duplex. The mature miRNA strand is then selectively loaded onto miRISC complexes where miRNA-directed targeting of mRNAs will take place leading to specific proteins expression deregulation which can play a role in stimulating cancer progression, whereas the miRNA* strand is preferentially degraded. Thus, blocking these miRNAs may lead to inhibition of cancer progression.

Cell-free circulating miRNAs (ci-miRNAs) were initially identified by Chim et al. (2018), as they noted that miRNAs are differentially expressed in the placenta and plasma of pregnant women [64]. Cell-free ci-miRNAs facilitate cellular signaling and are presently considered as plausible biomarkers for several diseases [65]. Ci-miRNAs are of two kinds, vesicle-associated and non-vesicle-associated, which suggest the distinct mean of their secretion. While, the majority of ci-miRNAs are present in a non-vesicle-associated form (ribonucleoprotein complex) [66-68], membrane-bound vesicles (exosomes and microvesicles) are isolated and purified from plasma/serum [69-71].

Depending on their origin, ci-miRNAs play a role in various cellular processes and target gene expression in recipient cells, thus, favoring cellular differentiation, proliferation as well as apoptosis [72]. Several investigations attempted to elucidate the underlying mechanism of ci-miRNA release, packaging and uptake, some suggesting that the process may involve selective packaging and release mechanisms [73]. In general, methods of miRNA release into circulation include exosomes/microvesicles, L-exosome, lipoproteins, and RNA-protein complex in addition to release by damaged cells due to necrosis or inflammation $[63,67,74,75]$. In general, miRNAs are selectively packaged into exosomes and become a critical part of the disease microenvironment; which is one of the underlying mechanisms of ci-miRNAs tissue/disease specificity. For instance, post-injury, ci-miRNAs$21,-122,-192,-200 c,-208$ and -423 are generally released from the heart, liver and kidney [76-79]. While, other ci-miRNAs are found to be involved in the onset and development of tumor progression as well as in the invasion and metastasis of cancer [80]. In this regard, release of immunosuppressive miRNAs allows cancer cells damage by $\mathrm{T}$ and $\mathrm{B}$ cells; on the other hand, angiogenic miRNAs allow cancer cells to recruit capillary blood vessels, thus promoting inflammation and angiogenesis. Moreover, it has been pointed out that dysregulation of ci-miRNA expression significantly enhances growth and spread of cancer cells [81-83]. MiRNAs released from tumor cells and immunocytes act synergistically ensuing poor clinical outcomes [84-86]. More importantly, ci-miRNAs can be associated with specific tumor progression stages as they are differentially expressed during different stages of cancer, thus, playing a 
vital role in carcinogenesis and its progression [87]. Based on these studies it is clear that ci-miRNAs could be used as promising biomarkers and therapeutic targets for different types of cancers including estrogen-receptor negative breast cancers (Figure 1).

\section{Circulating miRNAs in HER2-Positive Breast Cancer}

MiRNAs play a vital role in controlling gene expression and therefore they are implicated in breast carcinogenesis [88]. MiRNAs are stable in blood, plasma, and serum and can be detected in circulation [63]. Recently, ci-miRNAs are being studied in breast cancer patients as promising diagnostic, predictive and prognostic biomarkers for the development of therapeutic strategies [89]. Identification of ci-miRNAs can serve as non-invasive and cost-effective biomarkers to help identify high-risk patients [90].

An earlier investigation by Fan et al. (2018) applied branched rolling circle amplification (BRCA) assay to analyze sera levels of ci-miRNAs as a means to detect early breast cancer. They were able to identify ci-miRNAs-16, $-21,-155$, and -195 in early breast cancer patients in comparison with healthy controls [91]. More recently, a study of breast cancer patients sera showed post-surgery loss of ci-miRNAs-130b-5p, -151a-5p, -206, and -222-3p compared to breast cancer group, where their expression were significantly elevated, thus implicating the important diagnostic and prognostic role for these five ci-miRNAs [87]. The study also reported that patients expressing three or more of these ci-miRNAs have shorter disease-free survival compared to those with 0-2 highly expressed ones [87]. Interestingly, the authors identified miR-222-3p as a candidate biomarker for the early detection and prognosis prediction of breast cancer [87]. Furthermore, qPCR analysis of breast cancer patient plasma samples reveal considerably elevated levels of ci- miRNA-21 and ci-miRNA-146a in breast cancer patients in comparison with healthy controls indicating their diagnostic potential for breast cancer [92]. Additionally, ci-miRNA-21 is significantly associated with lymph node involvement, metastasis, high tumor grade and advanced clinical stage [93-95], thus, confirming its role as a diagnostic and prognostic marker [93].

Several recent studies have shown that ci-miRNAs are present in breastmilk and are associated with mammary gland infections (mastitis) [96] as well as cancers [97-99] including breast cancer [73,97,100]. Interestingly, numerous investigations that identified ci-miRNAs in breastmilk concluded that they are immunity-modulating microRNAs [101-105]; few of them found that ci-miRNAs are differentially expressed in-vitro [73] and in-vivo [97] during the onset of breast cancer [106]. Ci-miRNAs-509-5p, $-515-3 p$, and -335 were the most profuse ci-miRNAs in the majority of body fluid samples including milk, however, ci-miRNA-193b was unique to breastmilk [107]. Moreover, Zhou et al., identified 10 ci-miRNAs (-148A-3P, -30B-5P, let-7f-5p, -146B-5P, -29A-3P, let-7a-5p, -141-3P, -182-5P, -200A-3P and -378-3P) in breastmilk [105]. Similarly, Munch et al., also found ci-miRNAs-148a, -200c, -146b-5p, -30d, $21,-103$, let-7b, let-7g, let-7a and let-7f in breastmilk [108]. Based on these studies and others, tumor suppressor let-7 family of miRNAs as the most common ci-miRNAs in milk from healthy patients; however, their expression was lost in patients with breast cancer as well as milk stasis, thus indicating a possible role of milk stasis in the onset of breast cancer [100,109-111]. While, ci-miRNA-181a was detected commonly in serum and breastmilk, some of the ci-miRNAs are found to be differentially expressed in different biological fluids of breast cancer patients in comparison with healthy controls [97]. Real-time PCR analysis identified the presence of ci-miRNAs-140, -21 and let-7a in breastmilk in higher abundance compared with blood [100]. However, data correlating the presence of ci-miRNAs in breastmilk and breast cancer is scarce and requires further investigations.

Ci-miRNAs are associated with HER2-positive breast cancers. Comprehensive de novo sequencing, of breast cancer patients' sera show significant association of ci-miRNAs-375 and -122 with clinical outcomes; elevated levels of ci-miRNA-122 is specifically predictive of metastatic recurrence in early stage (II-III) breast cancer patients [112]. Moreover, the study also analyzed differentially expressed ci-miRNAs in HER2-positive and HER2-negative breast cancer patients; elevated ci-miRNA-375 and reduced ci-miRNA-122 levels correlate with positive HER2 status, response to neoadjuvant 
chemotherapy and absence of relapse [112]. A recent report exhibited a differential expression of exosomal miR-101 and miR-373 in patients with breast cancer and benign breast tumors; exosomal miR-101 serum levels are deregulated in HER2-positive breast cancer in comparison to its levels in healthy women [113]. A recent study also analyzed ci-miRNAs in serum of breast cancer patients to identify subtype-specific molecular profiles of cell-free miRNAs for early detection of breast cancer in serum; the NanoString platform identified the 42 significant differentially expressed ci-mi-RNAs in each molecular subtype [114]. Of these 42, only four ci-miRNAs (ci-miRNAs- 548ar-5p, 584-3p, 615-3p and 1283) are expressed in the HER2-positive subtype [114].

Moreover, ci-miRNAs can potentially identify patients with differential response to HER2-targeted therapy [115]. A recent study conducted by Di Cosimo et al. (2020) used high-throughput analysis of 752 miRNA assays from HER2-positive breast cancer patients to identify differentially expressed ci-miRNAs before and after two weeks of trastuzumab administration [115]. The study reported enhanced levels of ci-miRNA-148a-3p and ci-miRNA-374a-5p, which are significantly associated with pathological complete response [115]. The same group analyzed ci-miRNAs as noninvasive biomarkers to predict efficiency of single/dual HER2-targeted therapy in the Neo ALTTO (Neoadjuvant Lapatinib and/or Trastuzumab Treatment Optimization) study. They found that levels of ci-miRNA-140-5p after two weeks of treatment correlate with prognosis in trastuzumab-responsive patients as well as event-free survival [116]. Another report found significant association between a panel of 3 ci-miRNAs (ci-miRNA-21, ci-miRNA-210, and ci-miRNA-373) and poor clinical outcome in HER2-positive non metastatic breast cancer patients treated with neo-adjuvant therapy, or adjuvant therapy \pm trastuzumab [117]. Furthermore, ci-miRNA-210 was thought to be a predictive factor of response to trastuzumab, tumor burden, and lymph node metastases [118]. On the other hand, a 2-ci-miRNA (miR-4734 and miR-150-5p) based signature is identified as a dependable prognostic biomarker for HER2 positive breast cancer patients [119]. Li et al. (2018) employed miRNA microarray and identified 13 differentially expressed ci-miRNAs in the serum of HER2-positive metastatic breast cancer patients with distinct response to trastuzumab; of these 13, four ci-miRNAs (ci-miRNAs-940, -451a, -16-5p and -17-3p) can predict trastuzumab therapeutic benefit in HER2-positive metastatic breast cancer patients [120].

Interestingly, Stevic et al. (2018) aimed to identify unique ci-miRNAs from plasma to distinguish HER2-positive breast cancer from TNBC compared with healthy women [121]. In comparison to the control, the levels of ci-miRNA-27a and ci-miRNA-365 are only significantly enhanced in HER2-positive patients, but not in TNBC patients [121]. On the other hand, ci-miR-27b is enhanced in both subtypes; however, comparatively higher exosomal levels have been detected in HER2-positive patients; HER2 triggers miR-27b expression via the AKT/NF- $\mathrm{KB}$ signaling cascade [121,122]. Furthermore, high exosomal miR-27b is found to predict pathological complete response in HER2-positive patients [121]. On the other hand, levels of exosomal miR-422a are decreased in HER2-positive breast cancer patients when compared to TNBC patients [121]. Based on clinicopathological characteristics, there is a significant correlation between ci-miRNAs-16, -328 and -660 and lymph node status in HER2-positive subtype but not in TNBC patients; additionally, ci-miRNA- 660 can be used to predict the pathological response to neoadjuvant therapy in HER2-positive patients [121]. Similarly, 6 ci-miRNAs (miR-185, miR-376a, miR-382, miR-410, miR-433, and miR-628) are associated with higher tumor size in HER2-positive breast cancer patients [121]. Microarray profiling and validation by qPCR in plasma from breast cancer patients identified a significant upregulation of ci-miRNA-107 in ER-negative patients compared with ER-positive patients [123]. Furthermore, plasma levels of miRNA-130a and miRNA-146a are significantly upregulated in HER2-positive breast cancer patients [123].

Table 1 summarizes key ci-miRNAs with their expression levels and biological functions in HER2-positive breast cancer. 
Table 1. List of ci-miRNAs and their roles in HER2-positive breast cancer.

\begin{tabular}{|c|c|c|c|}
\hline \multirow{2}{*}{ Biological Functions } & \multicolumn{2}{|c|}{ Circulating-miRNAs } & \multirow{2}{*}{ References } \\
\hline & Stimulate & Inhibit & \\
\hline $\begin{array}{l}\text { Drug Resistance and } \\
\text { Tumor Relapse }\end{array}$ & $\begin{array}{c}\text { miRNA-21/210/373, } \\
\text { miRNA-16-5p/17-3p/451a/940, } \\
\text { miRNA-26a-5p/106b-5p/150-5p/ } \\
\text { 155-5p/205-5p/361-5p/365a-3p }\end{array}$ & $\begin{array}{c}\text { miRNA-148a-3p/374a-5p, } \\
\text { miRNA-140-5p, } \\
\text { miRNA-375/122, } \\
\text { miRNA-27b/660, } \\
\text { miRNA-424-3p/4734 }\end{array}$ & {$[112,115-117,119-121]$} \\
\hline $\begin{array}{l}\text { Cell Migration and } \\
\text { Proliferation }\end{array}$ & $\begin{array}{l}\text { miRNA-27a/365/382, } \\
\text { miRNA-130a }\end{array}$ & $\begin{array}{l}\text { miRNA-628/598/422a, } \\
\text { miRNA-146a, } \\
\text { miRNA-107 }\end{array}$ & {$[121,123,124]$} \\
\hline Cell Apoptosis & miRNA-628/598/422a & miRNA-382 & [121] \\
\hline Angiogenesis & miR-27a & & {$[121,125]$} \\
\hline High Tumor Size & miRNA-185/376a/382/410/433/628 & & [121] \\
\hline $\begin{array}{l}\text { Tumor Metastasis } \\
\text { and Progression }\end{array}$ & $\begin{array}{c}\text { miRNA-27a/301/365/628 } \\
\text { miRNA-107/130a/146a }\end{array}$ & $\begin{array}{c}\text { miRNA-422a/598, } \\
\text { miRNA-146a, } \\
\text { miRNA-107 }\end{array}$ & {$[121,123,124]$} \\
\hline EMT & miRNA-382 & & [121] \\
\hline
\end{tabular}

\section{Circulating miRNAs in TNBC}

Today, with important advances made in genomic profiling more comprehensive screening of genetic signatures and their downstream targets is possible. In this context, a study by Souza et al. (2019) using NanoString platform was able to identify and quantify 42 differentially expressed ci-miRNAs in the serum of breast cancer patients [114]. Among these ci-miRNAs, the expression of miRNA-25-3p was elevated in TNBC patient serum in comparison with matched healthy controls [114]. Moreover, it has been revealed that ci-miRNAs-18b, $-103,-107$ and -652 significantly correlate with tumor recurrence and reduced survival in TNBC patients [126]. Furthermore, elevated levels of ci-miRNAs-21-5p, -375, -205-5p, -194-5p and reduced expression of ci-miRNas-382-5p, -376c-3p, -411-5p are also associated with recurrent breast cancer cases [127]. Moreover, upregulated expression of ci-miRNAs-21, -210 and -221 are found to be significantly involved in the onset and progression of TNBC [128].

A panel of four ci-miRNAs were identified in a recent miRNA profiling of TNBC patients that could be used as both diagnostic and prognostic biomarkers; three ci-miRNAs (miRNA-376c, miRNA-155 and miRNA-17a) are reported as early stage biomarkers, while, ci-miRNA-10b is found as late stage biomarker of TNBC [129]. Similarly, in the study by Stevic et al. (2018) significantly higher levels of exosomal miRNA-376c, miRNA-382 and miRNA-433 are observed in TNBC patients, but not in HER2-positive breast cancer patients [121]. Moreover, ci-miRNA-374 significantly correlates with a higher tumor size in TNBC patients [121]. Another investigation showed that a four serum miRNA signature (miRNA-16, miRNA-25, miRNA-222 and miRNA-324-3p) correlates with enhanced risk of breast cancer thus providing a non-invasive predictive biomarker [130]. The study also demonstrated that a combination of miRNAs-484 and -191 can be used as endogenous control for serum miRNA detection [130]. MiRNA profiling of TNBC patients from Metabric database revealed high expression of ci-miRNA-105 and ci-miRNA-93-3p in TNBC patients which is significantly associated with poor survival [131]. More specifically, it has been reported that miR-105/93-3p stimulates Wnt/ $\beta$-catenin signaling by reducing SFRP1 levels, which is associated with chemoresistance and metastasis in TNBC cells [131]. Notably, combination of ci-miRNA-105/93-3p levels indicate the presence of a potential diagnostic biomarker for both early- and late-stage TNBC [131].

A comparative study between ci-miRNAs in TNBC and non-TNBC patients using miRCURY LNA array platform and real-time PCR showed that loss of ci-miRNA-199a-5p correlates with disease stage, thus, suggesting its role as a plausible TNBC-specific diagnostic marker [90]. An investigation by 
Chen et al. (2016), further explored the underlying mechanism of ci-miRNA-199a-5p in TNBC revealing its role in EMT and blocking breast cancer cell stemness by reducing CD24-/CD44+ expression and ALDH activity [132]. TaqMan-based miRNA profiling in tumor, adjacent non-tumor, corresponding plasma from breast cancer patients, and plasma from matched healthy controls identified upregulation of miRNAs-16, -21 and -451 and downregulation of miRNA-145 in plasma of breast cancer patients [62]. Additionally, this study demonstrated a combination of miRNA-145 and miRNA-451 as a candidate biomarker for breast cancer in comparison with healthy controls and other types of cancers [62]. On the other hand, analysis by qPCR in TNBC patients revealed that the expression of ci-miRNA-34a/34b/34c is significantly reduced in TNBC patients compared to controls; while, low miRNA-34a/c expression correlate with tumor progression and worse prognosis and miRNA-34b is significantly associated with lymph node positivity [133]. More recently, a study by Ozawa et al. (2020), analyzed the expression of ci-miRNAs in breast cancer subtypes revealing that elevated ci-miRNA-142-5p expression distinguish luminal A subtype from TNBC, however, the accuracy was increased in combination with ci-miRNA-320a [134]. Moreover, ci-miRNAs expression was analyzed in a cohort of TNBC patients in comparison with estrogen and progesterone positive patient group (ER/PR); they concluded that ci-miRNA-200c expression is reduced in TNBC patients compared with the ER/PR positive group [135].

Zhu et al. (2018) analyzed the association of ci-angiogenic miRNAs and the incidence of cardiotoxicity in TNBC patients treated with neoadjuvant chemotherapy [136]. The study showed that in comparison with non-cardiotoxic patients, levels of ci-miRNAs- let-7f, -19a, -20a, -126, and -210 are reduced [136]. Further validation by RT-qPCR suggested use of let-7f and miRNA-126 as candidate biomarkers for cardiotoxicity risk in TNBC patients undergoing EC-D neoadjuvant chemotherapy [136]. Similarly, a study in Saudi female breast cancer patients, showed upregulation of ci-miRNA-let-7f in luminal breast cancer, while, ci-miR-195 is elevated in TNBC patients [137]. Eichelser et al. (2014) explored the expression of ci-miRNAs in blood sera of breast cancer patients using quantitative TaqMan MicroRNA assays; according to their findings, cell-free miRNAs- 101 and -373 can be used as breast cancer-specific markers, additionally, sera levels of exosomal (not cell-free) miR-373 are significantly higher in the TNBC subtype and in ER-/PR- breast cancer patients, thus, suggesting a correlation between miR-373 and negative receptor status [113]. Functional assays demonstrated that miRNA-373 reduces ER expression and induces cell growth and proliferation by camptothecin (a topoisomerase poison) [113].

Table 2 summarizes the key ci-miRNAs with their expression levels and biological functions in TNBC.

Table 2. List of ci-miRNAs and their roles in triple-negative breast cancer (TNBC).

\begin{tabular}{|c|c|c|c|}
\hline \multirow{2}{*}{$\begin{array}{l}\text { Biological } \\
\text { Functions }\end{array}$} & \multicolumn{2}{|l|}{ Circulating-miRNAs } & \multirow{2}{*}{ References } \\
\hline & Stimulate & Inhibit & \\
\hline $\begin{array}{c}\text { Drug Resistance } \\
\text { and Tumor Relapse }\end{array}$ & $\begin{array}{c}\text { miRNA-105/93-3p, } \\
\text { miRNA-18b/103/107/652, miRNA-202, } \\
\text { miRNA-21/210/221/222, } \\
\text { miRNA-130a-3p/451a, } \\
\text { miRNA-21-5p/375 }\end{array}$ & & [126-128,131,138,139] \\
\hline $\begin{array}{l}\text { Cell Migration and } \\
\text { Proliferation }\end{array}$ & $\begin{array}{l}\text { miRNA-101, miRNA-25-3p, } \\
\text { miRNA-21-5p, miRNA-17a, } \\
\text { miRNA-142-5p }\end{array}$ & $\begin{array}{l}\text { miRNA-199a-5p, } \\
\text { miR-891a-5p }\end{array}$ & $\begin{array}{c}{[90,113,114,121,127,129,} \\
140]\end{array}$ \\
\hline Cell Apoptosis & miRNA-142-5p & $\begin{array}{c}\text { miRNA-373, } \\
\text { miRNA-let-7f/126 }\end{array}$ & {$[113,136,140]$} \\
\hline Angiogenesis & miRNA-let-7f/126 & & [136] \\
\hline High Tumor Size & miRNA-374 & & [121] \\
\hline
\end{tabular}


Table 2. Cont.

\begin{tabular}{cccc}
\hline \multirow{2}{*}{$\begin{array}{c}\text { Biological } \\
\text { Functions }\end{array}$} & Circulating-miRNAs & References \\
\cline { 2 - 3 } $\begin{array}{c}\text { Tumor Metastasis } \\
\text { and Progression }\end{array}$ & $\begin{array}{c}\text { miRNA-34a/c, miRNA-155, } \\
\text { miRN-200c, miRNA-21/210/221, } \\
\text { miRNA-17a/376c }\end{array}$ & miRNA-628 & {$[121,128,129,133,135,141]$} \\
\hline EMT & $\begin{array}{c}\text { miRNA-199a-5p, miRNA-375, } \\
\text { miRNA-17a }\end{array}$ & \\
\hline
\end{tabular}

\section{The Role of ci-miRNAs in Cellular Signaling Pathways}

Several studies have shown that ci-miRNAs play a crucial role in dysregulating gene expression via several major pathways involved in inhibiting apoptosis and inducing breast cancer invasion and metastasis $[142,143]$. Pathway analysis of differentially expressed ci-miRNAs have indicated plausible cellular signaling pathways playing a vital role in breast cancer including TGF- $\beta$, p53, MAPK/ERK and Wnt signaling pathways [143-145].

In metastatic breast cancer, upregulated ci-miRNA-181a expression levels can be controlled by TGF $\beta$-SMAD signaling pathway, which further enhance the expression of the transcription factor, SNAIL-1 and inhibit Bim expression, thus, promoting breast tumor aggressiveness and metastasis via EMT [146]. Similar to ci-miRNA-181a, ci-miR-18a inhibit breast cancer induced lung metastasis by targeting SREBP1, which forms a SNAIL/HDAC1/2 complex to modulate EMT [147]. Moreover, ci-miRNA-200c expression is lost during EMT, therefore it is considered one of the hallmarks of breast cancer metastasis [148,149]. Ci-miRNA-200c family members control the expression of BMI1 in breast cancer cells and inhibit ZEB1/2 expression, thus reducing EMT [150,151]. Furthermore, miRNA-200c regulates, TGF- $\beta$ [144]; which is known to stimulate bone and lung metastases $[152,153]$. Furthermore, studies by Iorio et al., and Yan et al. showed that TGF- $\beta 1$ and the receptor TGF $\beta$ R2 are target genes of miRNA-21, indicating a role of TGF- $\beta$ in mediating miRNA-21-induced breast cancer [154,155]. Ci-miRNA-21 has several targets involved in breast tumorigenesis including PDCD4, TPM1 [156,157] and PTEN [158]. In breast cancer cells, overexpressing ci-miRNA-191, was associated with upregulated levels of TGF- $\beta$ pathway genes (TGF $\beta 2$, SMAD3, BMP4, JUN, FOS, PTGS2, CTGF, and VEGFA), thus promoting breast cancer growth and metastasis [159]. On the other hand, ci-miRNA-34a, is a key member of the p53 group; therefore, loss of both ci-miRNA-34a and p53 enhances tumor growth and promote breast cancer progression [145]. Several studies also showed that inducing the expression of miRNA-34a in breast cancer cells promote apoptosis and inhibit tumor suppression by increasing Bcl-2 and SIRT1 levels [145,160]. While, ci-miRNA-10b expression is enhanced via the transcription factor, twist and targets Krüppel-like factor 4 genes, which further inhibits the expression of HOXD10 and enhances the expression of pro-metastatic RHOC gene leading to tumor invasion and metastasis [161,162]. Moreover, Let-7 targets GTPase HRas and the high mobility group A2 (HGMA2), thus, regulating breast tumor-initiating cells [110].

Ci-miRNAs are also involved in regulating Wnt/ $\beta$-catenin and Notch signaling pathways, thus playing a vital role in controlling EMT and tumor metastasis/progression [142]. In this regard, elevated levels of ci-miRNA-374a inhibit the expression of epithelial markers (E-cadherin), and promote the expression of mesenchymal markers (N-cadherin and vimentin), thus enhancing EMT [163]. Moreover, miRNA-374a activates the $\mathrm{Wnt} / \beta$-catenin pathway by promoting nuclear translocation of $\beta$-catenin and targets negative regulators of the signaling pathway including PTEN and WNT5A [163]. Also, loss of ci-miRNA-148a targets WNT1, a ligand of the Wnt/ $\beta$-catenin pathway; thus, promoting breast cancer migration, invasion and metastasis [164]. On the other hand, loss of ci-miRNA-148a was found to promote breast cancer cell proliferation, colony formation, and tumor angiogenesis by targeting IGF-IR and IRS1 and upregulating their downstream AKT and MAPK/ERK signaling pathways [165]. On the other hand, loss of ci-miRNA-101 enhance the expression of Notch signaling 
pathways components including jagged1, Hes1, and Hey1, which results in apoptosis inhibition [166]. Additionally, loss of ci-miRNA-101 levels in breast cancer, inhibit apoptosis by upregulating SOX2 levels, thus, promoting breast cancer growth, proliferation and migration [167]. Downregulated ci-miRNA-424 expression in breast cancer cells enable the proliferation and regulation of cell cycle by allowing continuous cell accumulation in the G2-M cell phase [168]. Furthermore, ci-miRNA-424 act as a tumor suppressor by binding to cyclin-dependent kinase $C D K 1$ while reduced ci-miRNA-4242 levels enhance the expression of YAP and p-ERK1/2 of the Hippo and ERK pathways, respectively [168].

\section{Ci-miRNAs as Potential Biomarkers and Therapeutic Targets-Advantages and Limitations}

As mentioned earlier, ci-miRNAs released from primary tumors and surrounding cells are present in circulating body fluids. Nevertheless, although ci-miRNAs can be detected in virtually all body fluids (blood, serum, plasma, urine, breastmilk and saliva) [107], the amount of ci-miRNAs present in each fluid type varies, with the highest levels present in saliva, blood, breastmilk, and seminal fluid and the lowest in human urine $[63,69,107,169,170]$. Thus, ci-miRNAs are considered as a potential, non-invasive diagnostic and prognostic biomarkers for various diseases including cancer [170-172]. Furthermore, ci-miRNAs are easier to identify due to their locations upstream in signaling cascades.

Early detection and diagnosis in HER2-positive breast cancer and TNBC patients aids in providing a more favorable outcome in diseases management [173]. Ci-miRNAs are associated with clinical and pathological features and can target different genes and influence several signaling pathways, thus, indicating their role as plausible candidate diagnostic, prognostic as well as predictive breast cancer biomarkers [174]. Due to certain basic features, ci-miRNAs are ideal candidates for non-invasive cancer biomarkers $[63,75,175]$. These studies clearly indicate the importance of ci-miRNAs as non-invasive tools in the early diagnosis of breast cancer and the classification of its subtypes, as well as their role as potential therapeutic targets especially for oncomiRNAs (Figure 1).

Nevertheless, the idea of developing an accurate clinical panel of ci-miRNAs as cancer biomarkers poses several challenges; from the first step of sample collection through to processing and data analysis. Since ci-miRNAs have low concentrations, it is often difficult to measure their expression through miRNA profiling/qRT-PCR/microarrays [176]. Another foremost limitation in miRNA identification and analysis in body fluids is the need for an appropriate housekeeping gene for internal normalization [177]. Certain housekeeping genes, often used as internal normalization during miRNA analysis in various cells and tissues, are not viable in serum analysis since these controls are easily degraded and not detected in serum [177]. Indeed, ci-miRNA expression values varies between sera and plasma samples taken from the same individual, as total RNA concentration is generally higher in the serum than in the plasma, possibly due to the RNA released from blood cells and platelets [178]; This indicates that preliminary sample collection is a vital issue and specific care should be taken to exclude hemolyzed samples. Moreover, to overcome conflicting findings reported in studies, patient selection with appropriate clinical diagnosis is important, as they influence results derived from clinical data $[170,179]$. In addition to the importance of establishing proper norms for sample selection, the isolation technique is another area of concern. Identifying ci-miRNAs specific to breast cancer would require augmenting ci-miRNAs during isolation, which would further aid to differentiate tumor origin biomarkers. Moreover, their underlying mechanisms in oncogenesis/metastasis (Figure 1), expression in specific types of cancers, different tumor stages as well as in response to treatment are still unclear and warrant further investigation [176]. With respect to targeted therapy, few limitations are present, one of them being, restricted tissue specificity and permeability and hence, nanoparticles carrying miRNAs are now being designed for improved specificity and reduced immunotoxicity [180]. Additionally, in-vivo studies demonstrated that packaged artificial and modified miRNAs in exosomes enhance stability of miRNAs [181]. Nonetheless, preclinical studies involving animal models should be considered to validate the efficiency of blocking ci-oncomiRNAs in cancer therapy (Figure 1).

Although several studies have identified and reported various ci-miRNAs in breast cancer, there is lack of significant inferences with respect to identification of a single ci-miRNA panel to aid in breast 
cancer diagnosis. This discrepancy can be attributed to breast cancer heterogeneity and its complex biological behavior and clinical presentation.

\section{Conclusions}

Estrogen-receptor negative breast cancers (HER2+ and TNBC) have higher mortality rate, which necessitates the discovery of new specific biomarkers as both predictive and potential therapeutic targets. MiRNA analysis, especially its circulating form, as biomarkers for breast cancer is a rapidly evolving field that carries a lot of promise for early non-invasive diagnosis that can be easily integrated in routine blood tests and patient follow ups. Recent investigations have also shown that ci-miRNAs are detectable and differentially expressed in the plasma, thus indicating their role as favorable diagnostic biomarkers for breast cancer. Nevertheless, there are still a lot of challenges in introducing this novel promising breast cancer diagnosis tool; therefore, further studies are essential to determine their clinical utility, not to mention their possibly important role as oncogenes, in the development of novel human breast cancer therapeutic avenues, which can pave the way for more specific targeted approaches.

Author Contributions: Conceptualization, A.-E.A.M. and H.A.F; writing-original draft preparation, I.G.; writing-review and editing, B.R., S.V., H.A.F. and A.-E.A.M. All authors have read and agreed to the published version of the manuscript.

Funding: Our lab is supported by grants from Qatar University\#: QUCP-CMED-2019-1, QUHI-CMED-19/20-1 and QUCG-CMED-20/21-2.

Acknowledgments: We would like to thank A. Kassab for her critical reading of the manuscript. The publication of this article was funded by the Qatar National Library.

Conflicts of Interest: The authors declare no conflict of interest. The funders had no role in the design of the study; in the collection, analyses, or interpretation of data; in the writing of the manuscript, or in the decision to publish the results.

\section{Abbreviations}

$\begin{array}{ll}\text { BMI1 } & \text { B cell-specific Moloney murine leukemia virus } \\ \text { ci-miRNA } & \text { integration site 1 } \\ \text { EMT } & \text { Circulating-Micro-Ribonucleic Acid } \\ \text { ER } & \text { Epithelial-Mesenchymal Transition } \\ \text { HER2 } & \text { Human Epidermal Growth Factor Receptor } 2 \\ \text { HOXD10 } & \text { Homeobox 10 } \\ \text { miRNA } & \text { Micro-Ribonucleic Acid } \\ \text { Neo ALTTO } & \text { Neoadjuvant Lapatinib and/or Trastuzumab } \\ & \text { Treatment Optimisation } \\ \text { PDCD4 } & \text { Programmed cell death } 4 \\ \text { PD-L1 } & \text { Programmed Death-Ligand 1 } \\ \text { PR } & \text { Progesterone Receptor } \\ \text { PTEN } & \text { Phosphatase and tensin homolog } \\ \text { RHOC } & \text { Ras homolog family member C } \\ \text { SIRT1 } & \text { Sirtuin 1 } \\ \text { TGF- } \beta & \text { Transforming growth factor- } \beta \\ \text { TNBC } & \text { Triple Negative Breast Cancer } \\ \text { TPM1 } & \text { Tropomyosin 1 } \alpha \\ \text { UTR } & \text { Untranslated Region } \\ \text { YAP } & \text { Yes associated protein } \\ \text { ZEB } & \text { Zinc-finger E-box binding homeobox }\end{array}$




\section{References}

1. Ferlay, J.; Colombet, M.; Soerjomataram, I.; Mathers, C.; Parkin, D.M.; Piñeros, M.; Znaor, A.; Bray, F. Estimating the global cancer incidence and mortality in 2018: GLOBOCAN sources and methods. Int. J. Cancer 2019, 144, 1941-1953. [CrossRef]

2. Tao, Z.; Shi, A.; Lu, C.; Song, T.; Zhang, Z.; Zhao, J. Breast Cancer: Epidemiology and Etiology. Cell. Biochem. Biophys. 2015, 72, 333-338. [CrossRef]

3. Perou, C.M.; Sørlie, T.; Eisen, M.B.; Van de Rijn, M.; Jeffrey, S.S.; Rees, C.A.; Pollack, J.R.; Ross, D.T.; Johnsen, H.; Akslen, L.A.; et al. Molecular portraits of human breast tumours. Nature 2000, 406, 747-752. [CrossRef]

4. Koboldt, D.C.; Fulton, R.S.; McLellan, M.D.; Schmidt, H.; Kalicki-Veizer, J.; McMichael, J.F.; Fulton, L.L.; Dooling, D.J.; Ding, L.; Mardis, E.R.; et al. Comprehensive molecular portraits of human breast tumours. Nature 2012, 490, 61-70. [CrossRef]

5. Sørlie, T.; Tibshirani, R.; Parker, J.; Hastie, T.; Marron, J.S.; Nobel, A.; Deng, S.; Johnsen, H.; Pesich, R.; Geisler, S.; et al. Repeated observation of breast tumor subtypes in independent gene expression data sets. Proc. Natl. Acad. Sci. USA 2003, 100, 8418. [CrossRef]

6. Slamon, D.J.; Clark, G.M.; Wong, S.G.; Levin, W.J.; Ullrich, A.; McGuire, W.L. Human breast cancer: Correlation of relapse and survival with amplification of the HER-2/neu oncogene. Science 1987, 235, 177-182. [CrossRef]

7. Foulkes, W.; Smith, I.E.; Reis-Filho, J.S. Triple-negative breast cancer. N. Engl. J. Med. 2010, 363, 1938-1948. [CrossRef]

8. Putti, T.C.; El-Rehim, D.M.A.; Rakha, E.A.; Paish, C.E.; Lee, A.H.S.; Pinder, S.E.; Ellis, I.O. Estrogen receptor-negative breast carcinomas: A review of morphology and immunophenotypical analysis. Mod. Pathol. 2005, 18, $26-35$. [CrossRef]

9. Loibl, S.; Gianni, L. HER2-positive breast cancer. Lancet 2017, 389, 2415-2429. [CrossRef]

10. Wolff, A.C.; Hammond, M.E.H.; Allison, K.H.; Harvey, B.E.; Mangu, P.B.; Bartlett, J.M.S.; Bilous, M.; Ellis, I.O.; Fitzgibbons, P.; Hanna, W.; et al. Human Epidermal Growth Factor Receptor 2 Testing in Breast Cancer: American Society of Clinical Oncology/College of American Pathologists Clinical Practice Guideline Focused Update. Arch. Pathol. Lab. Med. 2018, 142, 1364-1382. [CrossRef]

11. Burstein, H.J. The distinctive nature of HER2-positive breast cancers. N. Engl. J. Med. 2005, 353, $1652-1654$. [CrossRef]

12. Irvin, W.; Carey, L.A. What is triple-negative breast cancer? Eur. J. Cancer 2008, 44, 2799-2805. [CrossRef]

13. Stockmans, G.; Deraedt, K.; Wildiers, H.; Moerman, P.; Paridaens, R. Triple-negative breast cancer. Curr. Opin. Oncol. 2008, 20, 614-620. [CrossRef]

14. Thike, A.; Cheok, P.Y.; Jara-Lazaro, A.R.; Tan, B.; Tan, P.; Tan, P.H. Triple-negative breast cancer: Clinicopathological characteristics and relationship with basal-like breast cancer. Mod. Pathol. 2010, 23, 123-133. [CrossRef]

15. Yadav, B.S.; Chanana, P.; Jhamb, S. Biomarkers in triple negative breast cancer: A review. World J. Clin. Oncol. 2015, 6, 252-263. [CrossRef]

16. Lin, N.; Claus, E.; Sohl, J.; Razzak, A.R.; Arnaout, A.; Winer, E.P. Sites of distant recurrence and clinical outcomes in patients with metastatic triple-negative breast cancer: High incidence of central nervous system metastases. Cancer 2008, 113, 2638-2645. [CrossRef]

17. Smid, M.; Wang, Y.; Zhang, Y.; Sieuwerts, A.M.; Yu, J.; Klijn, J.G.; Foekens, J.A.; Martens, J.W. Subtypes of breast cancer show preferential site of relapse. Cancer Res. 2008, 68, 3018-3114. [CrossRef]

18. Dent, R.; Hanna, W.M.; Trudeau, M.; Rawlinson, E.; Sun, P.; Narod, S.A. Pattern of metastatic spread in triple-negative breast cancer. Breast. Cancer Res. Treat. 2009, 115, 423-428. [CrossRef]

19. Ala-Eddin, A.L.; Moustafa, A.Y.; Lina Ghabreau Ali, H. Mohamed and Amal Achkhar. Brain Metastases Progression of Breast Cancer. In Breast Cancer; Mehmet, G., Gunduz, E., Eds.; Intech Open: London, UK, 2011. [CrossRef]

20. Haffty, B.; Yang, Q.; Reiss, M.; Kearney, T.; Higgins, S.A.; Weidhaas, J.; Harris, L.; Hait, W.; Toppmeyer, D. Locoregional relapse and distant metastasis in conservatively managed triple negative early-stage breast cancer. J. Clin. Oncol. 2006, 24, 5652-5657. [CrossRef] 
21. Heitz, F.; Harter, P.; Lueck, H.J.; Fissler-Eckhoff, A.; Lorenz-Salehi, F.; Scheil-Bertram, S.; Traut, A.; Du Bois, A. Triple-negative and HER2-overexpressing breast cancers exhibit an elevated risk and an earlier occurrence of cerebral metastases. Eur. J. Cancer 2009, 45, 2792. [CrossRef]

22. Marty, M.; Cognetti, F.; Maraninchi, D.; Snyder, R.; Mauriac, L.; Tubiana-Hulin, M.; Chan, S.; Grimes, D.; Antón, A.; Lluch, A.; et al. Randomized phase II trial of the efficacy and safety of trastuzumab combined with docetaxel in patients with human epidermal growth factor receptor 2-positive metastatic breast cancer administered as first-line treatment: The M77001 study group. J. Clin. Oncol. 2005, 23, 4265-4274. [CrossRef]

23. Geyer, C.E.; Forster, J.; Lindquist, D.; Chan, S.; Romieu, C.G.; Pienkowski, T.; Jagiello-Gruszfeld, A.; Crown, J.; Chan, A.; Kaufman, B.; et al. Lapatinib plus capecitabine for HER2-positive advanced breast cancer. N. Engl. J. Med. 2006, 355, 2733-2743. [CrossRef]

24. Peddi, P.F.; Hurvitz, S.A. Ado-trastuzumab emtansine (T-DM1) in human epidermal growth factor receptor 2 (HER2)-positive metastatic breast cancer: Latest evidence and clinical potential. Ther. Adv. Med. Oncol. 2014, 6, 202-209. [CrossRef]

25. Vranic, S.; Beslija, S.; Gatalica, Z. Targeting HER2 expression in cancer: New drugs and new indications. Bosn. J. Basic Med. Sci. 2020. [CrossRef]

26. Liedtke, C.; Mazouni, C.; Hess, K.R.; André, F.; Tordai, A.; Mejia, J.A.; Symmans, W.F.; Gonzalez-Angulo, A.M.; Hennessy, B.; Green, M.; et al. Response to neoadjuvant therapy and long-term survival in patients with triple-negative breast cancer. J. Clin. Oncol. 2008, 26, 1275-1281. [CrossRef]

27. Kassam, F.; Enright, K.; Dent, R.; Dranitsaris, G.; Myers, J.; Flynn, C.; Fralick, M.; Kumar, R.; Clemons, M. Survival outcomes for patients with metastatic triple-negative breast cancer: Implications for clinical practice and trial design. Clin. Breast Cancer 2009, 9, 29-33. [CrossRef]

28. Patel, S.P.; Kurzrock, R. PD-L1 Expression as a Predictive Biomarker in Cancer Immunotherapy. Mol. Cancer Ther. 2015, 14, 847-856. [CrossRef]

29. Gibney, G.T.; Weiner, L.M.; Atkins, M.B. Predictive biomarkers for checkpoint inhibitor-based immunotherapy. Lancet Oncol. 2016, 17, e542-e551. [CrossRef]

30. Vranic, S.; Cyprian, F.S.; Gatalica, Z.; Palazzo, J. PD-L1 status in breast cancer: Current view and perspectives. Semin. Cancer Biol. 2019. [CrossRef]

31. Cyprian, F.S.; Akhtar, S.; Gatalica, Z.; Vranic, S. Targeted immunotherapy with a checkpoint inhibitor in combination with chemotherapy: A new clinical paradigm in the treatment of triple-negative breast cancer. Bosn. J. Basic Med. Sci. 2019, 19, 227-233. [CrossRef] [PubMed]

32. Gonzalez-Angulo, A.M.; Morales-Vasquez, F.; Hortobagyi, G.N. Overview of resistance to systemic therapy in patients with breast cancer. Adv. Exp. Med. Biol. 2007, 608, 1-22. [CrossRef]

33. Brufsky, A. Trastuzumab-based therapy for patients with HER2-positive breast cancer: From early scientific development to foundation of care. Am. J. Clin. Oncol. 2010, 33, 186-195. [CrossRef]

34. Tang, Q.; Ouyang, H.; He, D.; Yu, C.; Tang, G. MicroRNA-based potential diagnostic, prognostic and therapeutic applications in triple-negative breast cancer. Artif. Cells Nanomed. Biotechnol. 2019, 47, 2800-2809. [CrossRef]

35. Gupta, I.; Sareyeldin, R.; Al-Hashimi, I.; Al-Thawadi, H.; Al Farsi, H.; Vranic, S.; Al Moustafa, A.-E. Progression of the triple negative breast cancer profile from gene to microRNA: An overview. Cancers 2019, 11, 363. [CrossRef]

36. Sareyeldin, R.M.; Gupta, I.; Al-Hashimi, I.; Al-Thawadi, H.A.; Al Farsi, H.F.; Vranic, S.; Al Moustafa, A.-E. Gene Expression and miRNAs Profiling: Function and Regulation in Human Epidermal Growth Factor Receptor 2 (HER2)-Positive Breast Cancer. Cancers 2019, 11, 646. [CrossRef]

37. Grimaldi, A.M.; Incoronato, M. Clinical Translatability of "Identified" Circulating miRNAs for Diagnosing Breast Cancer: Overview and Update. Cancers 2019, 11, 901. [CrossRef]

38. De Planell-Saguer, M.; Rodicio, M.C. Detection methods for microRNAs in clinic practice. Clin. Biochem. 2013, 46, 869-878. [CrossRef]

39. Molnár, V.; Tamási, V.; Bakos, B.; Wiener, Z.; Falus, A. Changes in miRNA expression in solid tumors: An miRNA profiling in melanomas. Semin. Cancer Biol. 2008, 18, 111-122. [CrossRef]

40. Pillai, R.S. MicroRNA function: Multiple mechanisms for a tiny RNA? RNA 2005, 11, 1753-1761. [CrossRef]

41. O’Brien, J.; Hayder, H.; Zayed, Y.; Peng, C. Overview of MicroRNA Biogenesis, Mechanisms of Actions, and Circulation. Front. Endocrinol. 2018, 9, 402. [CrossRef] 
42. Broughton, J.P.; Lovci, M.T.; Huang, J.L.; Yeo, G.W.; Pasquinelli, A.E. Pairing beyond the Seed Supports MicroRNA Targeting Specificity. Mol. Cell 2016, 64, 320-333. [CrossRef] [PubMed]

43. Cimmino, A.; Calin, G.A.; Fabbri, M.; Iorio, M.V.; Ferracin, M.; Shimizu, M.; Wojcik, S.E.; Aqeilan, R.I.; Zupo, S.; Dono, M.; et al. miR-15 and miR-16 induce apoptosis by targeting BCL2. Proc. Natl. Acad. Sci. USA 2005, 102, 13944-13949. [CrossRef] [PubMed]

44. Hayashita, Y.; Osada, H.; Tatematsu, Y.; Yamada, H.; Yanagisawa, K.; Tomida, S.; Yatabe, Y.; Kawahara, K.; Sekido, Y.; Takahashi, T. A polycistronic microRNA cluster, miR-17-92, is overexpressed in human lung cancers and enhances cell proliferation. Cancer Res. 2005, 65, 9628-9632. [CrossRef] [PubMed]

45. Hwang, H.W.; Mendell, J.T. MicroRNAs in cell proliferation, cell death, and tumorigenesis. Br. J. Cancer 2006, 94, 776-780. [CrossRef] [PubMed]

46. Nicoloso, M.S.; Spizzo, R.; Shimizu, M.; Rossi, S.; Calin, G.A. MicroRNAs-the micro steering wheel of tumour metastases. Nat. Rev. Cancer 2009, 9, 293-302. [CrossRef]

47. Ma, L.; Weinberg, R.A. Micromanagers of malignancy: Role of microRNAs in regulating metastasis. Trends. Genet. 2008, 24, 448-456. [CrossRef]

48. Welch, C.; Chen, Y.; Stallings, R.L. MicroRNA-34a functions as a potential tumor suppressor by inducing apoptosis in neuroblastoma cells. Oncogene 2007, 26, 5017-5022. [CrossRef]

49. He, L.; Thomson, J.M.; Hemann, M.T.; Hernando-Monge, E.; Mu, D.; Goodson, S.; Powers, S.; Cordon-Cardo, C.; Lowe, S.W.; Hannon, G.J.; et al. A microRNA polycistron as a potential human oncogene. Nature 2005, 435, 828-833. [CrossRef]

50. Yu, S.; Lu, Z.; Liu, C.; Meng, Y.; Ma, Y.; Zhao, W.; Liu, J.; Yu, J.; Chen, J. miRNA-96 suppresses KRAS and functions as a tumor suppressor gene in pancreatic cancer. Cancer Res. 2010, 70, 6015-6025. [CrossRef]

51. Esquela-Kerscher, A.; Slack, F.J. Oncomirs - microRNAs with a role in cancer. Nat. Rev. Cancer 2006, 6, 259-269. [CrossRef]

52. Sheinerman, K.S.; Toledo, J.B.; Tsivinsky, V.G.; Irwin, D.; Grossman, M.; Weintraub, D.; Hurtig, H.I.; Chen-Plotkin, A.; Wolk, D.A.; McCluskey, L.F.; et al. Circulating brain-enriched microRNAs as novel biomarkers for detection and differentiation of neurodegenerative diseases. Alzheimers Res. Ther. 2017, 9, 89. [CrossRef]

53. Navickas, R.; Gal, D.; Laucevičius, A.; Taparauskaitè, A.; Zdanytè, M.; Holvoet, P. Identifying circulating microRNAs as biomarkers of cardiovascular disease: A systematic review. Cardiovasc. Res. 2016, 111, 322-337. [CrossRef]

54. Jiménez-Lucena, R.; Camargo, A.; Alcalá-Diaz, J.F.; Romero-Baldonado, C.; Luque, R.M.; Van Ommen, B.; Delgado-Lista, J.; Ordovás, J.M.; Pérez-Martínez, P.; Rangel-Zúñiga, O.A.; et al. A plasma circulating miRNAs profile predicts type 2 diabetes mellitus and prediabetes: From the CORDIOPREV study. Exp. Mol. Med. 2018, 50, 1-12. [CrossRef]

55. Yuan, H.L.; Wang, T.; Zhang, K.H. MicroRNAs as potential biomarkers for diagnosis, therapy and prognosis of gastric cancer. OncoTargets Ther. 2018, 11, 3891-3900. [CrossRef]

56. Calin, G.A.; Croce, C.M. MicroRNA signatures in human cancers. Nat. Rev. Cancer 2006, 6, 857-866. [CrossRef]

57. Volinia, S.; Calin, G.A.; Liu, C.G.; Ambs, S.; Cimmino, A.; Petrocca, F.; Visone, R.; Iorio, M.; Roldo, C.; Ferracin, M.; et al. A microRNA expression signature of human solid tumors defines cancer gene targets. Proc. Natl. Acad. Sci. USA 2006, 103, 2257-2261. [CrossRef]

58. Brase, J.C.; Johannes, M.; Schlomm, T.; Fälth, M.; Haese, A.; Steuber, T.; Beissbarth, T.; Kuner, R.; Sültmann, H. Circulating miRNAs are correlated with tumor progression in prostate cancer. Int. J. Cancer 2011, 128, 608-616. [CrossRef]

59. Ng, E.K.; Chong, W.W.; Jin, H.; Lam, E.K.; Shin, V.Y.; Yu, J.; Poon, T.C.; Ng, S.S.; Sung, J.J. Differential expression of microRNAs in plasma of patients with colorectal cancer: A potential marker for colorectal cancer screening. Gut 2009, 58, 1375-1381. [CrossRef]

60. Tsujiura, M.; Ichikawa, D.; Komatsu, S.; Shiozaki, A.; Takeshita, H.; Kosuga, T.; Konishi, H.; Morimura, R.; Deguchi, K.; Fujiwara, H.; et al. Circulating microRNAs in plasma of patients with gastric cancers. Br. J. Cancer 2010, 102, 1174-1179. [CrossRef]

61. Shapira, I.; Oswald, M.; Lovecchio, J.; Khalili, H.; Menzin, A.; Whyte, J.; Dos Santos, L.; Liang, S.; Bhuiya, T.; Keogh, M.; et al. Circulating biomarkers for detection of ovarian cancer and predicting cancer outcomes. Br. J. Cancer 2014, 110, 976-983. [CrossRef] 
62. Ng, E.K.; Li, R.; Shin, V.Y.; Jin, H.C.; Leung, C.P.; Ma, E.S.; Pang, R.; Chua, D.; Chu, K.M.; Law, W.L.; et al. Circulating microRNAs as specific biomarkers for breast cancer detection. PLoS ONE 2013, 8, e53141. [CrossRef] [PubMed]

63. Mitchell, P.S.; Parkin, R.K.; Kroh, E.M.; Fritz, B.R.; Wyman, S.K.; Pogosova-Agadjanyan, E.L.; Peterson, A.; Noteboom, J.; O’Briant, K.C.; Allen, A.; et al. Circulating microRNAs as stable blood-based markers for cancer detection. Proc. Natl. Acad. Sci. USA 2008, 105, 10513-10518. [CrossRef] [PubMed]

64. Chim, S.S.; Shing, T.K.; Hung, E.C.; Leung, T.Y.; Lau, T.K.; Chiu, R.W.; Lo, Y.M. Detection and characterization of placental microRNAs in maternal plasma. Clin. Chem. 2008, 54, 482-490. [CrossRef]

65. Paul, P.; Chakraborty, A.; Sarkar, D.; Langthasa, M.; Rahman, M.; Bari, M.; Singha, R.S.; Malakar, A.K.; Chakraborty, S. Interplay between miRNAs and human diseases. J. Cell. Physiol. 2018, 233, 2007-2018. [CrossRef]

66. Wang, K.; Zhang, S.; Weber, J.; Baxter, D.; Galas, D.J. Export of microRNAs and microRNA-protective protein by mammalian cells. Nucleic Acids Res. 2010, 38, 7248-7259. [CrossRef]

67. Arroyo, J.D.; Chevillet, J.R.; Kroh, E.M.; Ruf, I.K.; Pritchard, C.C.; Gibson, D.F.; Mitchell, P.S.; Bennett, C.F.; Pogosova-Agadjanyan, E.L.; Stirewalt, D.L.; et al. Argonaute2 complexes carry a population of circulating microRNAs independent of vesicles in human plasma. Proc. Natl. Acad. Sci. USA 2011, 108, 5003-5008. [CrossRef] [PubMed]

68. Montani, F.; Bianchi, F. Circulating Cancer Biomarkers: The Macro-revolution of the Micro-RNA. EBioMedicine 2016, 5, 4-6. [CrossRef]

69. Valadi, H.; Ekström, K.; Bossios, A.; Sjöstrand, M.; Lee, J.J.; Lötvall, J.O. Exosome-mediated transfer of mRNAs and microRNAs is a novel mechanism of genetic exchange between cells. Nat. Cell. Biol. 2007, 9, 654-659. [CrossRef]

70. Taylor, D.D.; Gercel-Taylor, C. MicroRNA signatures of tumor-derived exosomes as diagnostic biomarkers of ovarian cancer. Gynecol. Oncol. 2008, 110, 13-21. [CrossRef]

71. Hunter, M.P.; Ismail, N.; Zhang, X.; Aguda, B.D.; Lee, E.J.; Yu, L.; Xiao, T.; Schafer, J.; Lee, M.L.; Schmittgen, T.D.; et al. Detection of microRNA expression in human peripheral blood microvesicles. PLoS ONE 2008, 3, e3694. [CrossRef]

72. Cui, M.; Wang, H.; Yao, X.; Zhang, D.; Xie, Y.; Cui, R.; Zhang, X. Circulating MicroRNAs in Cancer: Potential and Challenge. Front. Genet. 2019, 10, 626. [CrossRef]

73. Pigati, L.; Yaddanapudi, S.C.; Iyengar, R.; Kim, D.J.; Hearn, S.A.; Danforth, D.; Hastings, M.L.; Duelli, D.M. Selective release of microRNA species from normal and malignant mammary epithelial cells. PLoS ONE 2010, 5, e13515. [CrossRef]

74. Cheng, G. Circulating miRNAs: Roles in cancer diagnosis, prognosis and therapy. Adv. Drug. Deliv. Rev. 2015, 81, 75-93. [CrossRef]

75. Chen, X.; Ba, Y.; Ma, L.; Cai, X.; Yin, Y.; Wang, K.; Guo, J.; Zhang, Y.; Chen, J.; Guo, X.; et al. Characterization of microRNAs in serum: A novel class of biomarkers for diagnosis of cancer and other diseases. Cell Res. 2008, 18, 997-1006. [CrossRef]

76. Ramachandran, K.; Saikumar, J.; Bijol, V.; Koyner, J.L.; Qian, J.; Betensky, R.A.; Waikar, S.S.; Vaidya, V.S. Human miRNome profiling identifies microRNAs differentially present in the urine after kidney injury. Clin. Chem. 2013, 59, 1742-1752. [CrossRef]

77. Park, N.J.; Zhou, H.; Elashoff, D.; Henson, B.S.; Kastratovic, D.A.; Abemayor, E.; Wong, D.T. Salivary microRNA: Discovery, characterization, and clinical utility for oral cancer detection. Clin. Cancer Res. 2009, 15, 5473-5477. [CrossRef]

78. Wang, K.; Zhang, S.; Marzolf, B.; Troisch, P.; Brightman, A.; Hu, Z.; Hood, L.E.; Galas, D.J. Circulating microRNAs, potential biomarkers for drug-induced liver injury. Proc. Natl. Acad. Sci. USA 2009, 106, 4402-4407. [CrossRef]

79. Ji, X.; Takahashi, R.; Hiura, Y.; Hirokawa, G.; Fukushima, Y.; Iwai, N. Plasma miR-208 as a biomarker of myocardial injury. Clin. Chem. 2009, 55, 1944-1949. [CrossRef]

80. Wang, H.; Peng, R.; Wang, J.; Qin, Z.; Xue, L. Circulating microRNAs as potential cancer biomarkers: The advantage and disadvantage. Clin. Epigenet. 2018, 10, 59. [CrossRef]

81. Tili, E.; Croce, C.M.; Michaille, J.J. miR-155: On the crosstalk between inflammation and cancer. Int. Rev. Immunol. 2009, 28, 264-284. [CrossRef] 
82. Lu, L.F.; Boldin, M.P.; Chaudhry, A.; Lin, L.L.; Taganov, K.D.; Hanada, T.; Yoshimura, A.; Baltimore, D.; Rudensky, A.Y. Function of miR-146a in controlling Treg cell-mediated regulation of Th1 responses. Cell 2010, 142, 914-929. [CrossRef] [PubMed]

83. Veit, T.D.; Chies, J.A. Tolerance versus immune response-MicroRNAs as important elements in the regulation of the HLA-G gene expression. Transpl. Immunol. 2009, 20, 229-231. [CrossRef] [PubMed]

84. Monleón, I.; Martínez-Lorenzo, M.J.; Monteagudo, L.; Lasierra, P.; Taulés, M.; Iturralde, M.; Piñeiro, A.; Larrad, L.; Alava, M.A.; Naval, J.; et al. Differential secretion of Fas ligand- or APO2 ligand/TNF-related apoptosis-inducing ligand-carrying microvesicles during activation-induced death of human $\mathrm{T}$ cells. J. Immunol. 2001, 167, 6736-6744. [CrossRef]

85. Kim, S.H.; Lechman, E.R.; Bianco, N.; Menon, R.; Keravala, A.; Nash, J.; Mi, Z.; Watkins, S.C.; Gambotto, A.; Robbins, P.D. Exosomes derived from IL-10-treated dendritic cells can suppress inflammation and collagen-induced arthritis. J. Immunol. 2005, 174, 6440-6448. [CrossRef]

86. Valenti, R.; Huber, V.; Iero, M.; Filipazzi, P.; Parmiani, G.; Rivoltini, L. Tumor-released microvesicles as vehicles of immunosuppression. Cancer Res. 2007, 67, 2912-2915. [CrossRef]

87. Wang, Y.; Yin, W.; Lin, Y.; Yin, K.; Zhou, L.; Du, Y.; Yan, T.; Lu, J. Downregulated circulating microRNAs after surgery: Potential noninvasive biomarkers for diagnosis and prognosis of early breast cancer. Cell Death Discov. 2018, 4, 21. [CrossRef] [PubMed]

88. Serpico, D.; Molino, L.; Di Cosimo, S. microRNAs in breast cancer development and treatment. Cancer Treat. Rev. 2014, 40, 595-604. [CrossRef]

89. Van Schooneveld, E.; Wildiers, H.; Vergote, I.; Vermeulen, P.B.; Dirix, L.Y.; Van Laere, S.J. Dysregulation of microRNAs in breast cancer and their potential role as prognostic and predictive biomarkers in patient management. Breast Cancer Res. 2015, 17, 21. [CrossRef]

90. Shin, V.Y.; Siu, J.M.; Cheuk, I.; Ng, E.K.O.; Kwong, A. Circulating cell-free miRNAs as biomarker for triple-negative breast cancer. Br. J. Cancer 2015, 112, 1751-1759. [CrossRef]

91. Fan, T.; Mao, Y.; Sun, Q.; Liu, F.; Lin, J.-S.; Liu, Y.; Cui, J.; Jiang, Y. Branched rolling circle amplification method for measuring serum circulating microRNA levels for early breast cancer detection. Cancer Sci. 2018, 109, 2897-2906. [CrossRef]

92. Kumar, S.; Keerthana, R.; Pazhanimuthu, A.; Perumal, P. Overexpression of circulating miRNA-21 and miRNA-146a in plasma samples of breast cancer patients. Indian J. Biochem. Biophys. 2013, 50, 210-214.

93. Asaga, S.; Kuo, C.; Nguyen, T.; Terpenning, M.; Giuliano, A.E.; Hoon, D.S. Direct serum assay for microRNA-21 concentrations in early and advanced breast cancer. Clin. Chem. 2011, 57, 84-91. [CrossRef]

94. Toraih, E.A.; Mohammed, E.A.; Farrag, S.; Ramsis, N.; Hosny, S. Pilot Study of Serum MicroRNA-21 as a Diagnostic and Prognostic Biomarker in Egyptian Breast Cancer Patients. Mol. Diagn. Ther. 2015, 19, 179-190. [CrossRef]

95. Si, H.; Sun, X.; Chen, Y.; Cao, Y.; Chen, S.; Wang, H.; Hu, C. Circulating microRNA-92a and microRNA-21 as novel minimally invasive biomarkers for primary breast cancer. J. Cancer Res. Clin. Oncol. 2013, 139, $223-229$. [CrossRef]

96. Sun, J.; Aswath, K.; Schroeder, S.G.; Lippolis, J.D.; Reinhardt, T.A.; Sonstegard, T.S. MicroRNA expression profiles of bovine milk exosomes in response to Staphylococcus aureus infection. BMC Genom. 2015, 16, 806. [CrossRef]

97. Do Canto, L.M.; Marian, C.; Willey, S.; Sidawy, M.; Da Cunha, P.A.; Rone, J.D.; Li, X.; Gusev, Y.; Haddad, B.R. MicroRNA analysis of breast ductal fluid in breast cancer patients. Int. J. Oncol. 2016, 48, 2071-2078. [CrossRef]

98. Hesari, A.; Golrokh Moghadam, S.A.; Siasi, A.; Rahmani, M.; Behboodi, N.; Rastgar-Moghadam, A.; Ferns, G.A.; Ghasemi, F.; Avan, A. Tumor-derived exosomes: Potential biomarker or therapeutic target in breast cancer? J. Cell. Biochem. 2018, 119, 4236-4240. [CrossRef]

99. Decmann, Á.; Perge, P.; Nagy, Z.; Butz, H.; Patócs, A.; Igaz, P. Circulating microRNAs in the diagnostics of endocrine neoplasms. Orv. Hetil. 2017, 158, 483-490. [CrossRef]

100. Gu, Y.Q.; Gong, G.; Xu, Z.L.; Wang, L.Y.; Fang, M.L.; Zhou, H.; Xing, H.; Wang, K.R.; Sun, L. miRNA profiling reveals a potential role of milk stasis in breast carcinogenesis. Int. J. Mol. Med. 2014, 33, 1243-1249. [CrossRef]

101. Cui, J.; Zhou, B.; Ross, S.A.; Zempleni, J. Nutrition, microRNAs, and Human Health. Adv. Nutr. 2017, 8, 105-112. [CrossRef] 
102. Golan-Gerstl, R.; Elbaum Shiff, Y.; Moshayoff, V.; Schecter, D.; Leshkowitz, D.; Reif, S. Characterization and biological function of milk-derived miRNAs. Mol. Nutr. Food Res. 2017, 61, 1700009. [CrossRef]

103. Kosaka, N.; Izumi, H.; Sekine, K.; Ochiya, T. microRNA as a new immune-regulatory agent in breast milk. Silence 2010, 1, 7. [CrossRef]

104. Na, R.S.; E, G.X.; Sun, W.; Sun, X.W.; Qiu, X.Y.; Chen, L.P.; Huang, Y.F. Expressional analysis of immune-related miRNAs in breast milk. Genet. Mol. Res. 2015, 14, 11371-11376. [CrossRef]

105. Zhou, Q.; Li, M.; Wang, X.; Li, Q.; Wang, T.; Zhu, Q.; Zhou, X.; Wang, X.; Gao, X.; Li, X. Immune-related microRNAs are abundant in breast milk exosomes. Int. J. Biol. Sci. 2012, 8, 118-123. [CrossRef]

106. Eichner, L.J.; Perry, M.C.; Dufour, C.R.; Bertos, N.; Park, M.; St-Pierre, J.; Giguère, V. miR-378(*) mediates metabolic shift in breast cancer cells via the PGC-1 $\beta / E R R \gamma$ transcriptional pathway. Cell Metab. 2010, 12, 352-361. [CrossRef]

107. Weber, J.A.; Baxter, D.H.; Zhang, S.; Huang, D.Y.; Huang, K.H.; Lee, M.J.; Galas, D.J.; Wang, K. The microRNA spectrum in 12 body fluids. Clin. Chem. 2010, 56, 1733-1741. [CrossRef]

108. Munch, E.M.; Harris, R.A.; Mohammad, M.; Benham, A.L.; Pejerrey, S.M.; Showalter, L.; Hu, M.; Shope, C.D.; Maningat, P.D.; Gunaratne, P.H.; et al. Transcriptome profiling of microRNA by Next-Gen deep sequencing reveals known and novel miRNA species in the lipid fraction of human breast milk. PLoS ONE 2013, 8 , e50564. [CrossRef]

109. Hu, X.; Guo, J.; Zheng, L.; Li, C.; Zheng, T.M.; Tanyi, J.L.; Liang, S.; Benedetto, C.; Mitidieri, M.; Katsaros, D.; et al. The heterochronic microRNA let-7 inhibits cell motility by regulating the genes in the actin cytoskeleton pathway in breast cancer. Mol. Cancer Res. 2013, 11, 240-250. [CrossRef]

110. Yu, F.; Yao, H.; Zhu, P.; Zhang, X.; Pan, Q.; Gong, C.; Huang, Y.; Hu, X.; Su, F.; Lieberman, J.; et al. let-7 regulates self renewal and tumorigenicity of breast cancer cells. Cell 2007, 131, 1109-1123. [CrossRef]

111. Qian, P.; Zuo, Z.; Wu, Z.; Meng, X.; Li, G.; Wu, Z.; Zhang, W.; Tan, S.; Pandey, V.; Yao, Y.; et al. Pivotal role of reduced let-7g expression in breast cancer invasion and metastasis. Cancer Res. 2011, 71, 6463-6474. [CrossRef]

112. Wu, X.; Somlo, G.; Yu, Y.; Palomares, M.R.; Li, A.X.; Zhou, W.; Chow, A.; Yen, Y.; Rossi, J.J.; Gao, H.; et al. De novo sequencing of circulating miRNAs identifies novel markers predicting clinical outcome of locally advanced breast cancer. J. Transl. Med. 2012, 10, 42. [CrossRef] [PubMed]

113. Eichelser, C.; Stückrath, I.; Müller, V.; Milde-Langosch, K.; Wikman, H.; Pantel, K.; Schwarzenbach, H. Increased serum levels of circulating exosomal microRNA-373 in receptor-negative breast cancer patients. Oncotarget 2014, 5, 9650-9663. [CrossRef] [PubMed]

114. Souza, K.C.B.; Evangelista, A.F.; Leal, L.F.; Souza, C.P.; Vieira, R.A.; Causin, R.L.; Neuber, A.C.; Pessoa, D.P.; Passos, G.A.S.; Reis, R.M.V.; et al. Identification of Cell-Free Circulating MicroRNAs for the Detection of Early Breast Cancer and Molecular Subtyping. J. Oncol. 2019, 2019, 8393769. [CrossRef] [PubMed]

115. Di Cosimo, S.; Appierto, V.; Pizzamiglio, S.; Silvestri, M.; Baselga, J.; Piccart, M.; Huober, J.; Izquierdo, M.; De la Pena, L.; Hilbers, F.S.; et al. Early Modulation of Circulating MicroRNAs Levels in HER2-Positive Breast Cancer Patients Treated with Trastuzumab-Based Neoadjuvant Therapy. Int. J. Mol. Sci. 2020, 21, 1386. [CrossRef] [PubMed]

116. Di Cosimo, S.; Appierto, V.; Pizzamiglio, S.; Tiberio, P.; Iorio, M.V.; Hilbers, F.; De Azambuja, E.; De la Peña, L.; Izquierdo, M.; Huober, J.; et al. Plasma miRNA Levels for Predicting Therapeutic Response to Neoadjuvant Treatment in HER2-positive Breast Cancer: Results from the NeoALTTO Trial. Clin. Cancer Res. 2019, 25, 3887-3895. [CrossRef]

117. Müller, V.; Gade, S.; Steinbach, B.; Loibl, S.; Von Minckwitz, G.; Untch, M.; Schwedler, K.; Lübbe, K.; Schem, C.; Fasching, P.A.; et al. Changes in serum levels of miR-21, miR-210, and miR-373 in HER2-positive breast cancer patients undergoing neoadjuvant therapy: A translational research project within the Geparquinto trial. Breast Cancer Res. Treat. 2014, 147, 61-68. [CrossRef]

118. Jung, E.J.; Santarpia, L.; Kim, J.; Esteva, F.J.; Moretti, E.; Buzdar, A.U.; Di Leo, A.; Le, X.F.; Bast, R.C., Jr.; Park, S.T.; et al. Plasma microRNA 210 levels correlate with sensitivity to trastuzumab and tumor presence in breast cancer patients. Cancer 2012, 118, 2603-2614. [CrossRef]

119. Du, F.; Yuan, P.; Zhao, Z.T.; Yang, Z.; Wang, T.; Zhao, J.D.; Luo, Y.; Ma, F.; Wang, J.Y.; Fan, Y.; et al. A miRNA-based signature predicts development of disease recurrence in HER2 positive breast cancer after adjuvant trastuzumab-based treatment. Sci. Rep. 2016, 6, 33825. [CrossRef] 
120. Li, H.; Liu, J.; Chen, J.; Wang, H.; Yang, L.; Chen, F.; Fan, S.; Wang, J.; Shao, B.; Yin, D.; et al. A serum microRNA signature predicts trastuzumab benefit in HER2-positive metastatic breast cancer patients. Nat. Commun. 2018, 9 , 1614. [CrossRef]

121. Stevic, I.; Müller, V.; Weber, K.; Fasching, P.A.; Karn, T.; Marmé, F.; Schem, C.; Stickeler, E.; Denkert, C.; Van Mackelenbergh, M.; et al. Specific microRNA signatures in exosomes of triple-negative and HER2-positive breast cancer patients undergoing neoadjuvant therapy within the GeparSixto trial. BMC Med. 2018, 16, 179. [CrossRef]

122. Jin, L.; Wessely, O.; Marcusson, E.G.; Ivan, C.; Calin, G.A.; Alahari, S.K. Prooncogenic Factors miR-23b and miR-27b Are Regulated by Her2/Neu, EGF, and TNF- $\alpha$ in Breast Cancer. Cancer Res. 2013, 73, 2884-2896. [CrossRef] [PubMed]

123. Stückrath, I.; Rack, B.; Janni, W.; Jäger, B.; Pantel, K.; Schwarzenbach, H. Aberrant plasma levels of circulating miR-16, miR-107, miR-130a and miR-146a are associated with lymph node metastasis and receptor status of breast cancer patients. Oncotarget 2015, 6, 13387-13401. [CrossRef] [PubMed]

124. Hurst, D.R.; Edmonds, M.D.; Scott, G.K.; Benz, C.C.; Vaidya, K.S.; Welch, D.R. Breast cancer metastasis suppressor 1 up-regulates miR-146, which suppresses breast cancer metastasis. Cancer Res. 2009, 69, 1279-1283. [CrossRef] [PubMed]

125. Tang, W.; Yu, F.; Yao, H.; Cui, X.; Jiao, Y.; Lin, L.; Chen, J.; Yin, D.; Song, E.; Liu, Q. miR-27a regulates endothelial differentiation of breast cancer stem like cells. Oncogene 2014, 33, 2629-2638. [CrossRef]

126. Sahlberg, K.K.; Bottai, G.; Naume, B.; Burwinkel, B.; Calin, G.A.; Børresen-Dale, A.-L.; Santarpia, L. A Serum MicroRNA Signature Predicts Tumor Relapse and Survival in Triple-Negative Breast Cancer Patients. Clin. Cancer Res. 2015, 21, 1207-1214. [CrossRef]

127. Huo, D.; Clayton, W.M.; Yoshimatsu, T.F.; Chen, J.; Olopade, O.I. Identification of a circulating microRNA signature to distinguish recurrence in breast cancer patients. Oncotarget 2016, 7, 55231-55248. [CrossRef]

128. Radojicic, J.; Zaravinos, A.; Vrekoussis, T.; Kafousi, M.; Spandidos, D.A.; Stathopoulos, E.N. MicroRNA expression analysis in triple-negative (ER, PR and Her2/neu) breast cancer. Cell Cycle 2011, 10, 507-517. [CrossRef]

129. Shaheen, J.; Shahid, S.; Shahzadi, S.; Akhtar, M.W.; Sadaf, S. Identification of Circulating miRNAs as Non-Invasive Biomarkers of Triple Negative Breast Cancer in the Population of Pakistan. Pakistan J. Zool. 2019, 51, 1113-1121. [CrossRef]

130. Hu, Z.; Dong, J.; Wang, L.E.; Ma, H.; Liu, J.; Zhao, Y.; Tang, J.; Chen, X.; Dai, J.; Wei, Q.; et al. Serum microRNA profiling and breast cancer risk: The use of miR-484/191 as endogenous controls. Carcinogenesis 2012, 33, 828-834. [CrossRef]

131. Li, H.-Y.; Liang, J.-L.; Kuo, Y.-L.; Lee, H.-H.; Calkins, M.J.; Chang, H.-T.; Lin, F.-C.; Chen, Y.-C.; Hsu, T.-I.; Hsiao, M.; et al. miR-105/93-3p promotes chemoresistance and circulating miR-105/93-3p acts as a diagnostic biomarker for triple negative breast cancer. Breast Cancer Res. BCR 2017, 19, 133. [CrossRef]

132. Chen, J.; Shin, V.Y.; Siu, M.T.; Ho, J.C.W.; Cheuk, I.; Kwong, A. miR-199a-5p confers tumor-suppressive role in triple-negative breast cancer. BMC Cancer 2016, 16, 887. [CrossRef] [PubMed]

133. Zeng, Z.; Chen, X.; Zhu, D.; Luo, Z.; Yang, M. Low Expression of Circulating MicroRNA-34c is Associated with Poor Prognosis in Triple-Negative Breast Cancer. Yonsei Med. J. 2017, 58, 697-702. [CrossRef] [PubMed]

134. Ozawa, P.M.M.; Vieira, E.; Lemos, D.S.; Souza, I.L.M.; Zanata, S.M.; Pankievicz, V.C.; Tuleski, T.R.; Souza, E.M.; Wowk, P.F.; Urban, C.d.A.; et al. Identification of miRNAs Enriched in Extracellular Vesicles Derived from Serum Samples of Breast Cancer Patients. Biomolecules 2020, 10, 150. [CrossRef]

135. Sebastian, N.; Janusz, P.; Bożena, S.; Zofia, P.; Jeziorski, A. Serum Levels of Circulating miRNA-21, miRNA-10b and miRNA-200c in Triple-Negative Breast Cancer Patients. Ginekologia Polska 2018, 89, 415-420. [CrossRef]

136. Zhu, Z.; Li, X.; Dong, H.; Ke, S.; Zheng, W.H. Let-7f and miRNA-126 correlate with reduced cardiotoxicity risk in triple-negative breast cancer patients who underwent neoadjuvant chemotherapy. Int. J. Clin. Exp. Pathol. 2018, 11, 4987-4995.

137. Qattan, A.; Intabli, H.; Alkhayal, W.; Eltabache, C.; Tweigieri, T.; Amer, S.B. Robust expression of tumor suppressor miRNA's let-7 and miR-195 detected in plasma of Saudi female breast cancer patients. BMC Cancer 2017, 17, 799. [CrossRef]

138. Joosse, S.A.; Müller, V.; Steinbach, B.; Pantel, K.; Schwarzenbach, H. Circulating cell-free cancer-testis MAGE-A RNA, BORIS RNA, let-7b and miR-202 in the blood of patients with breast cancer and benign breast diseases. Br. J. Cancer 2014, 111, 909-917. [CrossRef] 
139. Ouyang, M.; Li, Y.; Ye, S.; Ma, J.; Lu, L.; Lv, W.; Chang, G.; Li, X.; Li, Q.; Wang, S.; et al. MicroRNA Profiling Implies New Markers of Chemoresistance of Triple-Negative Breast Cancer. PLoS ONE 2014, 9, e96228. [CrossRef]

140. Xu, W.; Wang, W. MicroRNA-142-5p modulates breast cancer cell proliferation and apoptosis by targeting phosphatase and tensin homolog. Mol. Med. Rep. 2018, 17, 7529-7536. [CrossRef]

141. Zhu, W.; Qin, W.; Atasoy, U.; Sauter, E.R. Circulating microRNAs in breast cancer and healthy subjects. BMC Res. Notes 2009, 2, 89. [CrossRef]

142. Loh, H.Y.; Norman, B.P.; Lai, K.S.; Rahman, N.; Alitheen, N.B.M.; Osman, M.A. The Regulatory Role of MicroRNAs in Breast Cancer. Int. J. Mol. Sci. 2019, 20, 4940. [CrossRef]

143. Aggarwal, V.; Priyanka, K.; Tuli, H.S. Emergence of Circulating MicroRNAs in Breast Cancer as Diagnostic and Therapeutic Efficacy Biomarkers. Mol. Diagn. Ther. 2020, 24, 153-173. [CrossRef]

144. Jurmeister, S.; Baumann, M.; Balwierz, A.; Keklikoglou, I.; Ward, A.; Uhlmann, S.; Zhang, J.D.; Wiemann, S.; Sahin, Ö. MicroRNA-200c represses migration and invasion of breast cancer cells by targeting actin-regulatory proteins FHOD1 and PPM1F. Mol. Cell. Biol. 2012, 32, 633-651. [CrossRef] [PubMed]

145. Yamakuchi, M.; Ferlito, M.; Lowenstein, C.J. miR-34a repression of SIRT1 regulates apoptosis. Proc. Natl. Acad. Sci. USA 2008, 105, 13421-13426. [CrossRef] [PubMed]

146. Rashed, L.; Faiz, S.; Hassan, M.; Elsebaie, M.; Saad, A. Circulating Micro RNA 181A as Biomarker in Breast Cancer, Its Possible Association with Metastasis \& Epithelial Mesenchymal Transformation. Tumori. J. 2020, 106, 3. [CrossRef]

147. Shen, K.; Cao, Z.; Zhu, R.; You, L.; Zhang, T. The dual functional role of MicroRNA-18a (miR-18a) in cancer development. Clin. Trans. Med. 2019, 8, 32. [CrossRef] [PubMed]

148. Huber, M.A.; Azoitei, N.; Baumann, B.; Grünert, S.; Sommer, A.; Pehamberger, H.; Kraut, N.; Beug, H.; Wirth, T. NF-kappaB is essential for epithelial-mesenchymal transition and metastasis in a model of breast cancer progression. J. Clin. Investig. 2004, 114, 569-581. [CrossRef]

149. Yang, J.; Mani, S.A.; Donaher, J.L.; Ramaswamy, S.; Itzykson, R.A.; Come, C.; Savagner, P.; Gitelman, I.; Richardson, A.; Weinberg, R.A. Twist, a master regulator of morphogenesis, plays an essential role in tumor metastasis. Cell 2004, 117, 927-939. [CrossRef]

150. Korpal, M.; Lee, E.S.; Hu, G.; Kang, Y. The miR-200 family inhibits epithelial-mesenchymal transition and cancer cell migration by direct targeting of E-cadherin transcriptional repressors ZEB1 and ZEB2. J. Biol. Chem. 2008, 283, 14910-14914. [CrossRef]

151. Shimono, Y.; Zabala, M.; Cho, R.W.; Lobo, N.; Dalerba, P.; Qian, D.; Diehn, M.; Liu, H.; Panula, S.P.; Chiao, E.; et al. Downregulation of miRNA-200c links breast cancer stem cells with normal stem cells. Cell 2009, 138, 592-603. [CrossRef]

152. Gennarino, V.A.; D’Angelo, G.; Dharmalingam, G.; Fernandez, S.; Russolillo, G.; Sanges, R.; Mutarelli, M.; Belcastro, V.; Ballabio, A.; Verde, P.; et al. Identification of microRNA-regulated gene networks by expression analysis of target genes. Genome Res. 2012, 22, 1163-1172. [CrossRef]

153. Drabsch, Y.; Ten Dijke, P. TGF- $\beta$ signaling in breast cancer cell invasion and bone metastasis. J. Mammary Gland. Biol. Neoplasia 2011, 16, 97-108. [CrossRef]

154. Iorio, M.V.; Ferracin, M.; Liu, C.-G.; Veronese, A.; Spizzo, R.; Sabbioni, S.; Magri, E.; Pedriali, M.; Fabbri, M.; Campiglio, M.; et al. MicroRNA Gene Expression Deregulation in Human Breast Cancer. Cancer Res. 2005, 65, 7065-7070. [CrossRef] [PubMed]

155. Yan, L.X.; Huang, X.F.; Shao, Q.; Huang, M.Y.; Deng, L.; Wu, Q.L.; Zeng, Y.X.; Shao, J.Y. MicroRNA miR-21 overexpression in human breast cancer is associated with advanced clinical stage, lymph node metastasis and patient poor prognosis. RNA 2008, 14, 2348-2360. [CrossRef] [PubMed]

156. Zhu, S.; Si, M.L.; Wu, H.; Mo, Y.Y. MicroRNA-21 targets the tumor suppressor gene tropomyosin 1 (TPM1). J. Biol. Chem. 2007, 282, 14328-14336. [CrossRef]

157. Qian, B.; Katsaros, D.; Lu, L.; Preti, M.; Durando, A.; Arisio, R.; Mu, L.; Yu, H. High miR-21 expression in breast cancer associated with poor disease-free survival in early stage disease and high TGF-beta1. Breast Cancer Res. Treat. 2009, 117, 131-140. [CrossRef] [PubMed]

158. Wickramasinghe, N.S.; Manavalan, T.T.; Dougherty, S.M.; Riggs, K.A.; Li, Y.; Klinge, C.M. Estradiol downregulates miR-21 expression and increases miR-21 target gene expression in MCF-7 breast cancer cells. Nucleic Acids Res. 2009, 37, 2584-2595. [CrossRef] [PubMed] 
159. Nagpal, N.; Ahmad, H.M.; Chameettachal, S.; Sundar, D.; Ghosh, S.; Kulshreshtha, R. HIF-inducible miR-191 promotes migration in breast cancer through complex regulation of TGF $\beta$-signaling in hypoxic microenvironment. Sci. Rep. 2015, 5, 9650. [CrossRef]

160. Li, L.; Yuan, L.; Luo, J.; Gao, J.; Guo, J.; Xie, X. MiR-34a inhibits proliferation and migration of breast cancer through down-regulation of Bcl-2 and SIRT1. Clin. Exp. Med. 2013, 13, 109-117. [CrossRef]

161. Ma, L.; Teruya-Feldstein, J.; Weinberg, R.A. Tumour invasion and metastasis initiated by microRNA-10b in breast cancer. Nature 2007, 449, 682-688. [CrossRef]

162. Rowland, B.D.; Peeper, D.S. KLF4, p21 and context-dependent opposing forces in cancer. Nat. Rev. Cancer 2006, 6, 11-23. [CrossRef]

163. Cai, J.; Guan, H.; Fang, L.; Yang, Y.; Zhu, X.; Yuan, J.; Wu, J.; Li, M. MicroRNA-374a activates Wnt/ $\beta$-catenin signaling to promote breast cancer metastasis. J. Clin. Investig. 2013, 123, 566-579. [CrossRef] [PubMed]

164. Jiang, Q.; He, M.; Ma, M.-T.; Wu, H.-Z.; Yu, Z.-J.; Guan, S.; Jiang, L.-Y.; Wang, Y.; Zheng, D.-D.; Jin, F.; et al. MicroRNA-148a inhibits breast cancer migration and invasion by directly targeting WNT-1. Oncol. Rep. 2016, 35, 1425-1432. [CrossRef]

165. Xu, Q.; Jiang, Y.; Yin, Y.; Li, Q.; He, J.; Jing, Y.; Qi, Y.T.; Xu, Q.; Li, W.; Lu, B.; et al. A regulatory circuit of miR-148a/152 and DNMT1 in modulating cell transformation and tumor angiogenesis through IGF-IR and IRS1. J. Mol. Cell. Biol. 2013, 5, 3-13. [CrossRef] [PubMed]

166. Guan, H.; Dai, Z.; Ma, Y.; Wang, Z.; Liu, X.; Wang, X. MicroRNA-101 inhibits cell proliferation and induces apoptosis by targeting EYA1 in breast cancer. Int. J. Mol. Med. 2016, 37, 1643-1651. [CrossRef]

167. Wang, J.; Zeng, H.; Li, H.; Chen, T.; Wang, L.; Zhang, K.; Chen, J.; Wang, R.; Li, Q.; Wang, S. MicroRNA-101 Inhibits Growth, Proliferation and Migration and Induces Apoptosis of Breast Cancer Cells by Targeting Sex-Determining Region Y-Box 2. Cell. Physiol. Biochem. 2017, 43, 717-732. [CrossRef] [PubMed]

168. Xie, D.; Song, H.; Wu, T.; Li, D.; Hua, K.; Xu, H.; Zhao, B.; Wu, C.; Hu, J.; Ji, C.; et al. MicroRNA-424 serves an anti-oncogenic role by targeting cyclin-dependent kinase 1 in breast cancer cells. Oncol. Rep. 2018, 40, 3416-3426. [CrossRef]

169. Shen, J.; Stass, S.A.; Jiang, F. MicroRNAs as potential biomarkers in human solid tumors. Cancer Lett. 2013, 329, 125-136. [CrossRef]

170. Bottani, M.; Banfi, G.; Lombardi, G. Circulating miRNAs as Diagnostic and Prognostic Biomarkers in Common Solid Tumors: Focus on Lung, Breast, Prostate Cancers, and Osteosarcoma. J. Clin. Med. 2019, 8, 1661. [CrossRef]

171. Chin, L.J.; Slack, F.J. A truth serum for cancer-microRNAs have major potential as cancer biomarkers. Cell Res. 2008, 18, 983-984. [CrossRef]

172. Guay, C.; Regazzi, R. Circulating microRNAs as novel biomarkers for diabetes mellitus. Nat. Rev. Endocrinol. 2013, 9, 513-521. [CrossRef]

173. Chang, Y.F.; Hung, S.H.; Lee, Y.J.; Chen, R.C.; Su, L.C.; Lai, C.S.; Chou, C. Discrimination of breast cancer by measuring prostate-specific antigen levels in women's serum. Anal. Chem. 2011, 83, 5324-5328. [CrossRef]

174. Madhavan, D.; Zucknick, M.; Wallwiener, M.; Cuk, K.; Modugno, C.; Scharpff, M.; Schott, S.; Heil, J.; Turchinovich, A.; Yang, R.; et al. Circulating miRNAs as surrogate markers for circulating tumor cells and prognostic markers in metastatic breast cancer. Clin. Cancer Res. 2012, 18, 5972-5982. [CrossRef]

175. Gilad, S.; Meiri, E.; Yogev, Y.; Benjamin, S.; Lebanony, D.; Yerushalmi, N.; Benjamin, H.; Kushnir, M.; Cholakh, H.; Melamed, N.; et al. Serum microRNAs are promising novel biomarkers. PLoS ONE 2008, 3, e3148. [CrossRef]

176. Wang, W.T.; Chen, Y.Q. Circulating miRNAs in cancer: From detection to therapy. J. Hematol. Oncol. 2014, 7, 86. [CrossRef]

177. Sundarbose, K.; Kartha, R.V.; Subramanian, S. MicroRNAs as Biomarkers in Cancer. Diagnostics 2013, 3, 84-104. [CrossRef]

178. Wang, K.; Yuan, Y.; Cho, J.H.; McClarty, S.; Baxter, D.; Galas, D.J. Comparing the MicroRNA spectrum between serum and plasma. PLoS ONE 2012, 7, e41561. [CrossRef]

179. Graveel, C.R.; Calderone, H.M.; Westerhuis, J.J.; Winn, M.E.; Sempere, L.F. Critical analysis of the potential for microRNA biomarkers in breast cancer management. Breast Cancer (Dove Med. Press) 2015, 7, 59-79. [CrossRef] 
180. Chen, Y.; Gao, D.Y.; Huang, L. In vivo delivery of miRNAs for cancer therapy: Challenges and strategies. Adv. Drug. Deliv. Rev. 2015, 81, 128-141. [CrossRef]

181. Cortez, M.A.; Bueso-Ramos, C.; Ferdin, J.; Lopez-Berestein, G.; Sood, A.K.; Calin, G.A. MicroRNAs in body fluids-The mix of hormones and biomarkers. Nat. Rev. Clin. Oncol. 2011, 8, 467-477. [CrossRef]

(C) 2020 by the authors. Licensee MDPI, Basel, Switzerland. This article is an open access article distributed under the terms and conditions of the Creative Commons Attribution (CC BY) license (http://creativecommons.org/licenses/by/4.0/). 